\title{
Monsters in the Crown: Anatomizing Indian Thuggees through Orientalist Lens
}

\author{
Priyanka Pathak
}

\begin{abstract}
We are afraid of the unknown. Anything that challenges our validated identity with its creepy presence engenders uneasiness. We try to merge the unknown with the realm of our knowledge and reality, but the moment we realize that these unknown may have different nature of reality, we resist unification with these strangers, as that may obscure our own well framed reality. The anxiety and discomfort about the unseen, uncharted, uncategorized have always encouraged human beings to seek after an enlightened existence, where nothing under the sun slips into the vortex of incognizance. But this insatiable curiosity of Renaissance man has also made them bump into a different pattern of life that they have cautiously pressed at the periphery. Hence, society has an ambivalent attitude towards these outlying creatures. The normative structure of society overbearingly intends to disempower and domesticate these not so human entities. This is how humans have created 'Monsters,' to conceal all the disorders, anomalies, deformities, and disruptions behind a thin veil. But the divider between the humans and non-humans, well-formed and deformed, normal and abnormal, is so fragile that shuttling between the domains is regular instance. Natives for their culture, rituals, behavior may appear monstrous to the colonizers but when the people on throne practice barbarous deeds to exert power, do they also ally with monstrosity? This paper intends to unravel the mystery and history behind the presence of profuse monsters in European colonies and will critically discuss how Orientalist stereotypes help in constructing the phenomenon of 'Monsters'. Are thugs of India merely metaphors for colonizers who intentionally produced an embellished description or an enigma?
\end{abstract}

Keywords: Monsters, Thugs, Colonialism, Postcolonialism, Orientalism.

\section{Introduction}

"Let me go ... monster! Ugly wretch! You wish to eat me and tear me to pieces. You are an ogre',

The word 'monster' has its origin from Latin verb "monēre" meaning "to warn" or "to advice". Its noun form "monstrum" means "an evil omen". This "monstrum" eventually became "monstre" in Middle English and turned to "monster" in modern English ${ }^{\text {ii }}$. Etymologically, anything evil that warns or threatens can be termed as monster. The Latin verb "monēre" has another possible meaning, to "remind" iii. Evidently, the idea of monster is, as Costantini (2019) points out, "inherently demonstrative, it is that which appears, a sign, a signifier" (p. 22). Jerome Cohen (1996) illustrates the phrase further, "...the monstrum is etymologically 'that which reveals,' 'that which warns,' are glyphs that seek hierophant, like a letter on the page, the monster signifies something other than itself: it is always a displacement, always inhabits the gap between the time of upheaval that created it at the 
moment into which it is received, to be born again" (p. 3). Cohen implies that there lies a gap between what the word 'monster' literally means and what it alludes to. It is this gap that shelters the unease, anxiety, and fear of the unknown. This paper will critically discuss the origination, formation and consolidation of an imprecise figure in Western understanding"Monster". This paper intends to explore how some flawed observation and carelessly embellished narrations of antiquity made the term 'monster' move from its original meaning and infiltrate the European cultural narratives inappropriately. The eighteenth and nineteenth century Europe was dominated by imperialist ideologies. The fallacy of Western ideology triggered colonizers to present natives as monstrous incarnations. Enlightenment brought changes in domestic politics and policies, propagating 'liberty, equality and fraternity' but the same Enlightenment values provoked the imposition of European culture in colonies. The colour, demeanor, and customs of indigenous people were marked as monstrous whereas the methodical, organized, massive violence of the colonizers were justified as a procedure of cultivating barbarous natives. With reference to colonizer's monster making tool this paper will illustrate how misinformation has engendered the thuggee phenomena and used it for governance and domination. The paper promises to unravel the mystery and history behind the thuggees that became part of nineteenth century British phantasmagoria.

The agonizing cry of Victor Frankenstein's brother William while facing his death in Mary Shelley's Frankenstein (2003) explains a lot about the essential qualities for being a monster. Slaughtering a human definitely confirms the monstrosity of a being but more than the demonic power and vicious intention of the creature, what petrifies William is his 'ugly' physical appearance. William could discern the evil inside the Creature not through the intentions behind action but through the hideous look. Victor himself remarks regarding his own creation,

Oh! No mortal could support the horror of that countenance. A mummy again endued with animation could not be so hideous as that wretch. I had gazed on him while unfinished; he was ugly then; but when those muscles and joints were rendered capable of motion, it became a thing such as even Dante could not have conceived. (Shelley, 2003, p. 56)

The creator's anvil is not afraid of shaping a body different from others but the beholders cannot withstand this difference. When Victor Frankenstein was playing the role of the Creator, the zeal of creation made him ignore the hideousness of his creation but the moment he slipped into the character of a passive onlooker he took no time to associate ugliness with monstrosity. J. R. R. Tolkien (1983) comments on the reason behind such attitude,"...to us evil and ugliness seem indissolubly allied. We find it difficult to conceive of evil and beauty together" (Tolkein, 1983, p. 151). Tolkien's remark emphasizes that idea of monstrosity is in no way a moral or spiritual slippage; rather it is profoundly hinged with flesh and body. The unusual demeanor of a human being makes him labeled as the 'other'. Mark Kirby (2000) explains, "This is partly due to the fact that 'abnormality' is mainly socially constructed: society determines what is abnormal and there are no objective criteria. Therefore what tends to be considered abnormal is that which does not fit in with particular society's definition of normal" (Kirby, 2000, p. 128). This abnormality can be innate or developed, physical or mental, maleficent or innocuous but variation from what is generally considered to be 'healthy human' appearance has always been intimidating to humanity as it exhibits the failure of the Creator. The 'normal' is perceived to be reflection of love and affection of bountiful God whereas the 'abnormal' manifests His wrath and imperfection. Therefore in popular belief abnormal can be allied with the evil and as because the iniquity resides in the soul, there are possibilities of moralizing souls. Saint Augustine asserts that God took the pleasure of creating the monsters so that their fall may act as a lesson to the virtuous. Robert Taylor (1828) quotes from a pseudo-Augustian sermon, "Ad Fratres in Eremo", in Syntagma of the Evidences of the Christian Religion: "I was already Bishop of Hippo, when I went into Ethiopia with some servants of Christ there to preach the Gospel. In 
this country we saw many men and women without heads, who had two great eyes in their breasts; and in countries still more south, we saw people who had but one eye in their foreheads" (Taylor, 1828, p. 92). St. Augustine thus claims to have stumbled upon numerous strange creatures in various distant lands and painstakingly records their strangeness in the form of Cyclops, Cynocephali, Sciopodes, and Blemmyae. Among these, some are described to have one leg instead of two, or their eyes are situated on the forehead. These body features though are portrayed as malformations but not as shortcomings, as they do not prevent the creatures from performing their regular activities smoothly. Despite such physical anomalies, the creatures are stated to be equally capable in their movements and works as the prototypical human beings. Therefore St. Augustine (2009) shows generous attitude towards these monsters, "...whoever is anywhere born a man, that is, a rational mortal animal, no matter what unusual appearance he presents in color, movement, sound, nor how peculiar he is in some power, part or quality of his nature, no Christian can doubt that he springs from that one protoplast. We can distinguish the common human nature from that which is peculiar and therefore wonderful',iv (Augustine, 2009, p. 424). But what conflicts with this generous benignity is Augustine's spurious account of indigene. As Augustine's attitude towards monsters in the City of God is hardly comparable with his sermons, Stephen T. Asma (2009) reads Augustine's sermons as "probably a twelfth-century apocryphal fake" (Asma, 2009, p. 77). But, at the same time, this supposition also bespeaks the popular perception regarding residents of foreign lands and these fictitious writings widely circulated as Augustine's sermons indicate how xenophobia was celebrated. Such attitude towards the strange abnormalities of inhabitants in remote places was perhaps constructed by the daemonic figures of folklores. Epics have fed these folklores well through ages. After the exhaustive Trojan war, when the titular hero of Homer's The Odyssey was sailing home with his men and ships, they landed on an island inhabited by Cyclops whom Homer (1900) describes as "a horrid creature, not like a human being at all, but resembling rather some crag that stands out boldly against the sky on the top of a high mountain" (Homer, 1900, p. 310). The gigantic Cyclop named Polyphemus proved to be a serious threat to Greek armies as it dashed a few of Odysseus' men 'upon the ground as though they had been puppies. Their brains were splashed upon the ground and the Earth was wet with their blood. Then he tore them limb from limb and dined upon them. He gobbled them up like a lion in the wilderness, flesh, bones, marrow, and entrails, without leaving anything uneaten" (Homer, 1900, p. 310). These wayward figures were believed to possess inhuman powers that can annihilate humans without even leaving traces of their existence. One of the great Greek victorious leaders Odysseus had to drop his human identity and call himself "Noman" to protect his life from this slayer. Almost three centuries after Homerv ${ }^{v}$, Aeschylus (1908) makes Prometheus warn the wandering Io saying,

Beware the Gryphon pack, the hounds of Zeus,

As keen of fang as silent of their tongues!

Beware the one-eyed Arimaspian band

That tramp on horse-hoofs, dwelling by the ford

Of Pluto and the stream that flows with gold:

Keep thou aloof from these. To the world's end

Thou comest at the last, the dark-faced tribe

That dwell beside the sources of the sun,

Where springs the river, Aethiopian named.

Make thou thy way along his bank,... (Morshed, 1908, p. 203)

Mostly the warriors and traders, visiting foreign lands provided embellished narrations of these chimeric figures which the epics, travel narratives and natural histories validated ${ }^{\mathrm{vi}}$. What these narratives also focused apart from the hideousness, is the vicious activities of the terrible creatures and their fascination with harming and slaying human being. These fictitious travel accounts injected in Europeans so much of trepidation and despise against the 
inhabitants of foreign lands that the explorers of sixteenth and seventeenth century appeared to an unknown place with an expectation of finding monster incarnations. Christopher Columbus expecting to find what Marco Polo described as the refined human society of East stumbled upon the Caribbean natives. While sketching one of them, Columbus (1999) says,

The native was, says the admiral, very deformed in appearance, more so than others he had seen: he had his face completely blackened with charcoal, even though everywhere there the natives are in the habit of painting themselves in different colors. He wore all his hair very long, gathered and tied in back, and then placed in a little net of parrot feathers; and he was naked, just like others. The admiral judged that he must have been one of the Caribs, who eat people. (p. DB 107)

The deformity mentioned here no longer identifies the de-formation of a human body rather a practice that is alien to the Europeans. The explorers could not compare the natives with the mythical demons that they were supposed to encounter in a foreign land. But as the European superiority was inculcated in their mind, they could not accept the difference as variety, rather tried to impose the demonic features on the newly witnessed practices. The coloured natives replaced the gigantic figures but could not cast off the attribute of a man eater. The culture and customs of indigenous inhabitants were deliberately misconstrued because their physical appearance could not please the aesthetic mind of the colonizers. Their appearance, movement, ideas, behaviour, belief, custom, religion, everything was viewed obliquely and categorized as monstrous which is in need of immediate edification. Annegret Marten (2018) poignantly remarks on the consequences of this, "On closer examination, however, it turns out to be a visual testament to how the colonial imagination was riddled with paradoxes. In the name of spreading culture and religion, colonizers committed atrocious massacres and other crimes. Laying early seeds for globalization, the self-interest-led conflicts between the different imperial powers resulted in innumerable barbaric acts of violence against the people, these empires enslaved and displaced" (Marten, 2018, p. 200). The monstrous body represents a space of colonizer's rejection and abhorrence, at the same time, a fascination towards the wealth of unknown lands. Therefore, the depiction of native's monstrosity somehow offers the colonizers a chance to deflect the attention and defend their own monstrous activities which in turn, also validates the criminality that they inflict on native 'monsters'.

Alexander in his letter to Aristotle mentions the man devouring monsters of India while narrating the calamity that Macedonian army faced in the deserts of the Indus Valley. After defeating King Porus of the Paurava kingdom in the Battle of the Hydaspes, the Alexandrian army invaded deeper into the Indian Territory, chasing the defeated Emperor. But soon the arid deserts of Indus exhausted the Greek legion and in search of water they reached an island castle surrounded by a poisonous river. Alexander's troop there encountered naked barbarians whose demeanour was akin to Columbus' portrayal of the native Indians of America. When a number of Macedonians were wading through the river the islanders plunged into the water and Alexander gasped, "We saw emerging from the deep a number of hippopotamuses, bigger than elephants. We could only watch and wail as they devoured the Macedonians whom we had sent to swim the river." (Stoneman, 2019, p. 47). These apocryphal accounts of India and its inhabitants uphold a fabricated image of exotic India, the 'land of snake charmers'. Alexander further notes, when his army finally reached a "lake of sweet water" (Stoneman, 2019, p. 45), and with some relief settled to have rest, legions of giant snakes, dragons, crocodiles, crabs, and even gigantic behemoths attacked the hapless brigade, who applied their arms ineffectively on the monstrous creatures. Outraged by this turmoil, Alexander appeared as the knight in shining armour and taught his men the monster slaying technique. Reiteration of such stories about India since antiquity endorses the existence of monsters, protecting great natural treasures. This also surely claims the need of a Cadmus who will slay the monsters and found Boetia for his own race. East India Company in the nineteenth century assumed the role of such a 'Hero', that appeared to civilize, 
rationalize and educate an ignorant race who, as James Mill (1958) scathingly remarked, are able to express themselves only in "the language of passion" (Mill, 1958, p. 33) and the legends and myth of which land are, "offspring of a wild and ungoverned imagination" that "mark the state of a rude and credulous people, whom the only marvels delights." (Mill, 1958, p. 115)

East India Company gradually rose to power, as their financial gain was increasing with the revenues from Bengal. On the other hand, allying with the native Kings in domestic battles was expanding their domination. But this could not stabilize the financial gains of Company ${ }^{\text {vii }}$. Avik Ray (2008) illustrates this crisis while referring the establishment of first Western style bank in Bengal in 1770 and outlining the evolution of modern banking in India, "In the meantime, the war unleashed by Marquis of Wellesley, Governor General of India between 1798 to 1805, against Tipu Sultan and the Marathas and the continuous demand of the East India Company for regular tribute from Indian tax revenues has placed the East India Company's Government in Bengal under severe financial strain" (Ray, 2008, p. 259). Though the domestic conflicts that paved the Company's way in Indian territory were mostly manipulated by the Company itself, but there was a constant threat from the petty zaminders and their subjects, who were prone to revolts. The only weapon to apply against these nuisance making natives was the legal technicalities.

Thomas Perry, East India Company's new magistrate in the district of Etawah claimed to have seen almost sixty dead corpses in wells and ditches near busy highways which led him to declare a thousand rupee reward for unraveling the mystery behind these deaths. The confession first came from Ghulam Hussain, an agricultural laborer. Later his associates also acknowledged their crime of looting and murdering the highway passengers who weree mostly tradesmen and pilgrims. These convicts then provided a diligent detail of their heinous deed. They named the process of murdering, "Ramsooth", where they, "strangled him (the victim) with a handkerchief; when he was senseless one of the party inflicted wounds with a knife in both eyes and another wounded him, in the same manner, in his belly so that no person might recognize the body..." (Dash, 2005, p. 32). Such was the process of murder that least evidence could be gathered against the murderers. Therefore officials had to rely on confessions and suspicion which made legal prosecution difficult. In 1810 Perry started arresting numerous natives suspecting them guilty of such murderous acts and thus East India Company first came across the idea of 'thuggee'. Perry made these criminals responsible for the disappearance of numerous natives and also claimed that these heinous villains were bred by local zaminders, who often employed them for making nuisance and to keep their subjects under threat. Because of the lack of evidence, many suspected were freed from Nizamat Adalat viii and Perry was admonished for arresting people only on suspicion. But in next decades William Sleeman managed to reveal the presence of thuggee as a threat to Colonial rule and he became the General Superintendent of the Thugge and Dacoity Department in 1835. After a year this turned in to an act, Thuggee and Dacoity Suppression Act 1836-1848. William Sleeman (2009) defined thuggee to the Editor of Calcutta Literary Gazette, as, "an organized system of religious and civil polity prepared to receive converts from all religions and sects and to urge them to the murder of their fellow creatures under the assurance of high rewards in this world and the other" (Sleeman, 2009, p. 176).Sleeman also described this practice as hereditary and motivated by religion. According to him, the consequence of discharging thuggees for the lack of evidence was scattered throughout but the commoners were either petrified or excessively naïve to act as a witness. He also portrayed the thuggees as a specific Hindu tribe, who worshipped goddess Kali. While anticipating the harm that these backward Hindu villains can cause, Sleeman (2009) swiftly associates them with the peripheral creatures that have warned them and caused threat to their dominance and power, "The hand of these inhuman monsters being against every one, and there being no country... in which they have not committed murder." (Sleeman, 2009, pp. 47-48) 
Sleeman's framing of thuggee made it a cult in Western world and his venture to eradicate thuggee was viewed as a noble attempt purging India of its maladies. William Butler (2013) writes, “... in India there exists what is not found elsewhere on earth, a class of men whose trade is blood, who follow murder as a profession, and even perform it as a religious duty!" (Butler, 2013, p. 397). Throughout the late nineteenth century, numerous historians and officials of British colonies has addressed the thuggee phenomenon of India as an exceptionally inhuman act that cannot be paralleled with any other criminal act across the world. British army surgeon Henry Harpur Spry (1837) while estimating the capabilities of Indians says, "The histories of Germany, Spain, and Italy are harrowing as are their details of cold blooded slaughter. But they offer no counterpart equal in atrocity or extent to the horrible murders which have come to light in the prosecution of thugs." (Spry, 1837, p. 158). Spry further states that he accompanied once a band of thugs who accurately pointed the place where they have buried seven travelers twelve years before. Spry glorified Lord Bentinck for appointing Captain Sleeman especially to annihilate the "Thug monsters of the East" (Spry, 1837, p. 160) and also approved the process of apprehending the thugs by procuring their confessions, which Spry declared to be undoubtable. Such sensational account of thugs can also be witnessed in Butler's personal reminiscences of India. Butler (2013) recounts how after a visit to Taj Mahal, Sleeman leaded them through a dark, dingy passage to an "inclosed court", and there, to his utter surprise he beholded, "... some of the most awful looking men that I had ever seen. The colonel Coolly remarked, 'These are some of my pets.' In a moment we realized where we were standing, three gentlemen and a party of ladies unguarded, in the very presence of nearly two hundred Thugs! It made one's flesh creep"(p. 399). Butler's account of the thuggee enlightens the complicacy of the occurrences. He states how the rise of Sepoys unleashed these monsters, whom the native rulers could not control. He described his experience "of seeing these monsters" just after visiting Taj as, "leaving paradise and descending into hell" which made him acknowledge India as a land of "millions utterly uneducated, and debased in conscience and morals..." (Butler, 2013, p. 397). Colonizers successfully shaped a monster out of a rebel or a mere criminal, residing in the land of treasure, as fantasized. What made thugs more sensational in West is their association with Eastern religion. Slaughtering to please a native deity gives the crime a demonic light. Julia A. Stone (1877) expresses her disgust on how like the "monsters in human shape" their worshipped deity is also a "monster Shiva, or Kahlee - I believe she is called by both names - feasting on human flesh: or as she is frequently represented, just staying her appetite a little, by eating an infant - this puzzles me"(p. 177). The distorted representation of religion, culture, behavior and even the crimes of natives have aided the monster making process of West since ancient ages.

British historian C.A. Bayly (1996) has insisted that the entire phenomenon has its root in 'information panic' created by the colonial administrators to bring under control their newly occupied northern and central territories of India. In 1801 British ceded these part of the country and the region was out of their knowledge as well as dominance. Hence the newly appointed magistrate Thomas Perry had to curve the law but unfortunately he failed in acquiring judicial support which Sleeman successfully acquired. Mike Dash (2005) while revisiting the interview of Ghulam Hussain expressed his doubts about its credibility. With time the intensity of Ghulam's crime increased in his interview. Dash observes that more than admitting himself as a thug, Ghulam went on confessing greater number of murders in successive interrogations which confirms his interrogator's maneuvering his statements. Perhaps apprehending this Ghulam Ali and his suspected associates were dismissed and Perry was admonished for accusing the natives without any proper evidence or witness. But within a decade or two of this incident the colonial administration of entire nation started considering thugs as a serious threat to innocent common native folks and hence sanctioned 'Anti-Thug Campaign'. Amal Chatterjee (1998) notes, "Thugs, once 'discovered', sprang up all across India" (Chatterjee, 1998, p. 3). Hegemonic view towards indigenous life and the colonial administrator's intention of solidifying the law-and-order of the state induced the 
administrators to illustrate thuggee.

The term 'thugs' has its origin in Sanskrit, meaning deceiver. Van Woerkens (2002) while answering 'Who Were the Thuggees?' accepts the existence of the thuggees in precolonial India straightly. The British colonizers indeed encountered a distinct way of robbery in India and also the phenomenon of thuggee was age old. But the void between actual thug and the oriental thug has generated this fantabulous phenomenon. In Upadeshmala, a $12^{\text {th }}$ century Jain text, the term 'thagavidya' gets mentioned, but that too employs the term as a deceiver ${ }^{\mathrm{ix}}$. Kim A. Wagner in Thuggee: Banditry and the British in Early Nineteenth Century India, provides historical evidences of the presence of thugs in pre-colonial India. Referring Firoz Shah Tughlak's biography he even mentions the event of exiling one thousand 'thags' from Delhi. Following H. M. Eliot, Darren Reid (2017) writes in her essay, 'On the Origin of Thuggee: Determining the Existence of Thugs in Pre-British India', "Even more revealing is Ziauddin Barani's 14th century history of Sultan Jalaluddin Firuz Khilji's reign, in which he describes how 'thieves were often brought before him....In his reign some thugs were taken in the city, and a man belonging to that fraternity was the means of about a thousand being captured" (Reid, 2017, p. 6). Though this account confirms the existence of thugs in India but does not illustrate their crime or method. These groups of criminals were described as thieves and deceivers, but no other heinous deed was attributed to them. In another interesting record of 1672 we find Aurangzeb ordering the Diwan of Gujrat, "A strangler whose act of strangulation has been legally proved should be chastised and confined till he repents. But if he is habituated to the work and the fact is proved... then execute him" (Sarkar, 1935, p.127). Interestingly, here stranglers are treated as a distinctly different group of criminals and are not to be confused with thugs or deceivers. Reference of thuggees also can be found in Janamsakhi, Guru Nanak's legendary biography. They appear here as mere deceivers who incidentally attempted to kill him. In each of these and numerous other references, what stands as remarkable is the disparity with which the idea of thuggee is presented. Hence the existence of thugs is indisputable but the myth surrounding them was an invention of colonizers. The violence that Anti Thug Campaign inflicted upon countless native massive and it evinced the colonizer's attempt of homogenizing the criminals to maintain their dominance. The 'thuggee' Act of 1836 instructs,

I. whoever shall be proved to have belonged, either before or after the passing of this Act, to any gang of Thugs, either within or without the Territories of the East India Company, shall be punished with imprisonment for life, with hard labour.

2. And ... every person accused of the offence ... may be tried by any court, which would have been competent to try him, if his offence had been committed within the Zillah where that Court sits, anything to the contrary, in any Regulation contained, notwithstanding.

3. And ... no Court shall, on a trial of any person accused of the offence ... require any Futwa from any Law officer. (Theobald, p. 78)

Act XXX of 1837, overtly attempts to uproot the Islamic Laws prevalent in India, and therefore dismisses the requirement of "futwa", but what remains surprising is circumventing the definition of the crime - 'thuggee'. The intention behind such misrepresentation is only to justify the brutality of colonization as welfare act of East India Company, to free India of its monsters. The havoc Perry's officials created at Murnae village near Bundelkhand was no less monstrous. Only because it was adjacent to Sindhouse village where Perry first marked the thugs, he assumed that several hundred have fled to Murnae. His men rampaged the village killing numbers, destroying and burning people. E. M. Thornton gives details of this in his, Illustrations of the History and Practices of the Thugs. During the operation more than fourteen hundred thugs were hanged or transported for life and almost became a 'hero' freeing the Orient of its malice. Wagner (2004) rightly observes, "The process of persecution, imprisonment and interrogation of the thugs obviously changed the nature of thuggee, both in 
practical terms and conceptually" (Wagner, 2004, p. 955). It also questions the colonial 'knowledge-gathering' process that in order to suppress revolts and discipline the dissenters jeopardizes survival of the natives. The judicial system of the colonizers has to be questioned as well, as it parallels criminality and monstrosity without any proper evidence other than other than suspicion and deception. Thus, criminality has been legalized in history time and again to eradicate unproven 'Monstrosity'.

\title{
Endnotes
}

\begin{abstract}
i Victor Frankenstein's brother, William Frankenstein, scared by the Creature's appearance reacts thus in Mary Shelley's Frankenstein; or The Modern Prometheus. The Creature at first tried to befriend young William and even described him as "beautiful". However, when William, out of fear mistreated the Creature, he choked William to death. When in turn Victor accused the Creature of murdering his brother, the Monster averts the accusation to human society, "All men hate the wretched; how, then, must I be hated, who am miserable beyond all living things!" The Monster's charges stress how alienation, discrimination forces a being to monstrosity.
\end{abstract}

ii The Merriam Webster New Book Of Word Histories writes, "The word monster comes from the Latin "monstrum", meaning an "evil omen" which in turn seems to be derivative of the verb "monēre", meaning "to warn", "remind". From this Latin verb several other modern English words have derived and are used in the purpose of reminding or warning, like "demonstrate".

iii John Oswald in his A Dictionary of Etymology of the English Synonymes and Paronymes writes, "Monstr-o v. 1. To show, to point out; to tell or to declare: as demonstrate, to show or to prove with the highest degree of certainty; monster, a prodigy, a being out of the common course of nature; muster, to collect troops for review, to assemble".

${ }^{\text {iv }}$ St. Augustine writes in City of God, Book XV, "It pleased the Creator to produce them, that it might thus be demonstrated that neither beauty, nor yet size and strength, are of much importance to the wise man, whose blessedness lies in spiritual and immortal blessings, in far better and more enduring gifts, in the good things that are the peculiar property of the good, and are not shared by good and bad alike".

${ }^{v}$ Herodotus, the Greek historian, in his Life of Homer (which is often considered to be written by Pseudo-Herodotus) placed Homer's year of birth four centuries before his own (484 BC to 425 BC), making it around $850 \mathrm{BC}$. Robert Holmes Beck writes in Aeschylus, that the playwright was born in either 525 or $524 \mathrm{BC}$ or ten years later.

${ }^{\mathrm{vi}}$ Renowned as Pliny the Elder in the second chapter entitled, 'Wonderful Forms of Different Nations', of Book VI from his Natural History writes "... the Griffins, a kind of monster, with wings, as they are commonly represented..."

vii The constant financial challenge that East India Company faced in India questioned their calibre of administering such a vast region. J. Albert Rorabacher asserts that the "frequent financial instability alarmed those in positions of power, bringing to the forefront the moral dilemmas and problems inherent in such an enterprise. And when famine struck in Bengal - as much a natural catastrophe as it was a Company-inspired event - the Company's ability and authority reign over foreign territory was called into question" (p. 265).

viii East India Company's court located in Bengal.

${ }^{\text {ix }}$ Paul Dundas explains the word thaga as deceitfulness and vidya as worship, in his, "Some jain reference to the Thags and the Samsaramocaka".

\section{References}

Asma, Stephen. T. (2009). On monsters: An unnatural history of our worst fears. Oxford University Press.

Augustine, Aurelius. (2009). The city of God. (Marcus Dods, Trans.). Devoted Publishing, p 424. (Original work published ca. 413-426 ce).

Bayly, Christopher. A. (1993). Knowing the country: Empire and information in India, Modern Asian Study, 27 (1), pp. 3-43.

Beagon, Mary. (2014). Wondrousanimalsin classical antiquity. In Gordon Lindsay 
Campbell(Ed.),The Oxford handbook of animals in classical thought and life, Oxford University Press.

Beck, Robert. Holmes. (1975). Aeschylus: Playwright educator. The Hague.

Pliny. (2011). The natural history of pliny. (John Bostock, \& H. T. Riley, Trans). Nabu Press.

Burke, Edmund.(2015). A philosophical enquiry into the origin of our ideas of the Sublime and Beautiful. Oxford University Press.

Butler, William. (2013). The land of veda: Being personal reminiscences of India, its people, castes, thugs, and fakirs. University of California Press.

Chatterjee, Amal. (1998). Representations of India, 1740-1840. Macmillan.

Cohen, Jeffrey. Jerome (Ed.). (1996). Monster theory: Reading culture. University of Minnesota Press.

Colombo, Cristoforo., \& Francesca. Lardicci. (1999). A synoptic edition of the log of Columbus's first voyage. Brepols.

Costantini, Cristina. (2019).The monster's mystique. In Daniela Carpi (Ed.), Monsters and monstrosity, from the canon to the anti-canon: literary and juridical subversions, Walter de Gruyter GmbH.

Cope, Edward. Drinkard. (1887). The origin of the fittest: Essays on evolution. D. Appleton and Company.

Darren, Reid. (2007). On the origin of thuggee: Determining the existence of thugs in prebritish india. Researchgate.

https://www.researchgate.net/publication/333295709_On_the_Origin_of_Thuggee_D etermining_the_Existence_of_Thugs_in_Pre-British_India.

Dash, Mike. (2005). Thug: The true story of India's murderous cult. Granta Books.

Elliot, H. M. (1953). The history of India, as told by its own historians: The muhammadan period, the posthumous papers of the late Sir H.M. Elliot. Susil Gupta (India) Ltd.

Homer. (1900). The Odyssey. (Samuel Butler, Trans.). A. C. Fifield. (Original work published ca. 800-600 BCE ).

https://en.m.wikisource.org/wiki/The_Odyssey_(Butler).

Indiana jones and the temple of doom. (1984). (Steven Spielberg, Dir). Lucasfilm Ltd.

Kirby, Mark. (2000). Sociology in perspective. Heinemann.

Mandeville, John. (1990). The travels of sir John Mandeville. Macmillan. http://www.gutenberg.org/files/782/782-h/782-h.htm

Marten, Annegret. (2018). Ecological angst and encounter with scary flesh. In Emma Bridges \& Djibril al-Ayed (Ed.). Making monsters: A speculative and classical Anthology. Futurefire.net Publishing.

Mill, James. (1997). A history of british India. Routledge.

Morshed, E.D.A. (1908). The suppliant maidens, the persians, the seven against thebes, the prometheus bound of Aeschylus. Macmillan.

Oswald, John. (1866). A dictionary of etymology of the english synonymes and paronymes. Adam and Charles Black.

Ray, Abhik. (2008). Two centuries of apex banking: The state bank of India and the evolution of modern banking in India. In Gerald D Feldman \& Peter Hertner (Eds.), Finance and Modernization: A Transnational and Transcontinental Perspective for the Nineteenth and Twentieth Centuries(p. 259).Ashgate.

Rorabacher, J. Albert. (2016). Property, land, revenue, and policy: The east India company, C.1757-1825. Taylor \& Francis, p. 265.

Sarkar, Jadunath. (1935). Mughal administration. M.C. Sarkar.

Shelley, Mary. (2003). Frankenstein; or, The modern prometheus. Barnes \& Noble Classics.

Singha, Radhika. (1998). A despotism of law: Crime and justice in early colonial India. Oxford University Press.

Sleeman, William. (1836). Ramaseeana: Or a vocabulary of the peculiar language used by 
the thugs. Military Orphan Press.

Sleeman, William. (2009). To the editor of the Calcutta literary gazette. In Kim A Wagner (Ed.),Stranglers and bandits: A historical anthology of thugee(p. 176).Oxford University Press.

Spry, Henry Harpur. (1837). Modern India: With illustrations of the resources and capabilities of Hindustan (Vol. 1). Whittaker.

Stone, Julia. A. (1877). Illustrated India: Its princes and people. American Publishing Company.

Stoneman, Richard. (2019). The great experience of India. Princeton University Press.

Taylor, Philip Meadows. (2018). Confessions of a thug. Amazing Reads.

Taylor, Philip. Meadows . (1991). The Merriam Webster new book of word histories. Merriam Webster.

Taylor, Robert. (1828). Syntagma of the evidences of the christian religion. William Dugdale.

Theobald, W. (1844). The acts of the legislative council of India, with a glossary; an analyticalabstract prefixedto each act, and copious indexes. The British Library.

Tolkien, J. R. R. (1983). On fairy stories. The monsters and the critics and other essays, Harper Collins Publishers.

Wagner, Kim A. (2004). The deconstructed stranglers: A reassessment of thuggee. Modern Asian Studies, 38(4), pp. 931-963.

Woerkens, Martine van. (2002). The strangled traveler: Colonial imaginings and the thugs of India. Trans. Catherine. Tihanyi. University of Chicago Press.

\section{Bio-note}

Priyanka Pathak has graduated from Serampore College, Calcutta University, and acquired her Master's Degree in English Literature from Rabindra Bharati University, Kolkata. At present she has been working as a lecturer at Vidyasagar College, Kolkata, and has also been pursuing her Ph.D. Degree from the University of Burdwan, Department of English and Culture Studies. Her area of research is Victorian Novels and Culture.

Email ID: priyankapathak015@gmail.com 